\title{
Clash of Generations at Workplace: What does Business Ethics Mean to Different Generations in Turkey?
}

\author{
Gülem Atabay
}

Şebnem Penbek

Deniz Zaptçioğlu

Ela Burcu Ucel

\author{
Izmir University of Economics, Faculty of Economics and Administrative Sciences, \\ Department of Business Administration, Sakarya Street, No:156, 35330 Balcova-Izmir, Turkey. \\ Tel: 90232 4889871, sebnem.penbek@ieu.edu.tr
}

\section{Doi:10.5901/ajis.2013.v2n9p532}

\section{Abstract}

\begin{abstract}
Changing times and fast moving conditions force organizations and managers to find new ways to adopt and manage every day challenges of the business world. One of those everyday challenges is managing a diverse work force composed of employees from different ages. Due to the increasingly diversified nature of the work force, intergenerational differences on work place characteristics and attitudes are major possible sources of work place problems. As the literature on generational differences at work place is generally dominated by Western studies, by conducting this study, it is aimed to highlight the way generations perceive business ethics from Turkish organizational perspective. The research was designed with an exploratory nature and employed qualitative research methods. 18 semi-structured interviews with three generations: Baby Boomers, Generation $X$ and Generation $Y$ were conducted. The findings of the current study indicated that there are both some similarities and also differences in terms of business ethics perceptions of three generations.
\end{abstract}

Keywords: Generations, Generational Differences, Business Ethics

\section{Introduction}

Business ethics has attracted worldwide attention lately as a result of the huge ethical scandals of the last decade such as Enron and Worldcom (Ashforth, and Joshi, 2005). It is argued in the literature that ethics at work is not a sole unitary construct, rather it involves attitudes and beliefs leading to work behavior (Miller et al., 2002). As ethical orientation is also about work behavior, making ethically responsible and accountable decisions and ensuring that employees make such decisions, is a serious problem that managers face. Making those ethically responsible and accountable decisions is basically about business ethics which is defined as the process of responsible decision making in organizations (Hartman \& Dejardins, 2008:3). At the individual and group level, 'business ethics' studies examine ethical misconducts and the personal responsibilities which can also be called "personal ethics".

The current study aimed to identify business ethics from a generational perspective, the findings highlighted that different generations have their own definitions of business ethics.

\section{Theoretical Background}

\subsection{Business Ethics}

The discussion about 'ethics' has been the subject of societies, philosophers, and academicians for about 2500 years. The word "Ethics" is derived from the Greek word "Ethos" which means customs ${ }^{1}$ and pronounced very similar in most of the languages as; "Etik" in Turkish, "éthique" in French, "ética" in Spanish and "etica" in Italian. On the other hand, a more

\footnotetext{
${ }^{1} \mathrm{http}: / /$ www.merriam-webster.com/dictionary/ethos: Accessed as of 14.02 .2012
} 
recent concept about ethics, business ethics is defined as: "...business ethics comprises the principles, values and standards that guide behavior in the world of business... principles are specific and pervasive boundaries for behavior that are universal and absolute.." (Ferrell, Fraedrich and Ferrell, 2011).

The corporate financial scandals; some of which are mentioned above, challenged the business world throughout the first few years of the 21st century. These scandals confronted organizations to create and maintain ethical climate and to hire, socialize, and train employees on the basis of ethical behavior (Anand, Ashforth, and Joshi, 2005; Trevino, Weaver and Reynolds, 2006; Valesquez, 2012;). The major challenge in creating an ethical climate is the differences in perceptions of "business ethics" among different groups of employees. These differences may be based on various aspects such as; educational background, age, individual values, moral development, religious orientation, occupational factors, laws, regulations and ethical codes of the organizational settings (Halıcl, 2000;Jennings,2009; Ferrell et al, 2011; Velasquez,2012).

Among these aspects, the different age groups that the employees are members of may cause them to perceive certain work related issues differently than each other. There are studies examining age differences on personality, expectations from work and life, perceptions about the world, love, family and friends in both popular press and academe (Deal,2007;Elmore, 2010; Gesell, 2010; Joshi,et al, 2010; Lancaster and Stillman, 2004;Li and Nimon,2008;Marston, 2007;Sirias, Karp and Brotherton,2007;Nancy, 2009;Reisenwitz and lyer 2009; Salahuddin, 2010; Simons,2010; Twenge;2010; Hansen \& Leuty,2012;). Besides the accelerating interest in media, there are actually few empirical studies in academe which focused on the issue and they mostly have conflicting results about the generational differences on work related issues (Hansey \& Leuty, 2012).

\subsection{Generations}

The year 2013 designates the synthesis of three major generations in the workforce: Baby-Boomers, Generation $X$ and Generation Y, with different backgrounds and childhood stories (Simons, 2010). Therefore today, organizations are not only trying to integrate the different generations in their workforce but are also triggered to create ethical climates that suit the various needs of different generations (Hansen \& Leuty, 2012).

Diverse publications and nations classify generations differently (Chowdhury \& Coulter 2006; Lescohier 2006; Durkin 2008; Reed 2007). The most cited categorization of these three generations according to the year of birth is: Baby Boomers (born between 1946-1964), Generation X (born between 1965-1979 and Generation Y (born between 19801995) (Marston, 2007;1995).

The common ground and the most triggered remark of the literature about generations at work is the inconsistency of perceptions among the very basic work characteristics such as work values, work attitudes and work expectations (Stauffer, 1997; Loomis, 2000; Raths, 1999; Keaveney, 1997; Yu\&Miller, 2005). For instance, Twenge (2010) grouped the mostly tested variables under five headings as; business ethics, centrality and altruistic value; extrinsic and intrinsic values; social values; job satisfaction and intention to leave in his profound review about generational differences in work attitudes. According to Marston (2007) Baby Boomers differentiate themselves from their younger colleagues by using their understanding of business ethics as a weapon for superiority. Also, in another study, Meriac et all (2010) indicated that there are differences in the perception of business ethics among the three generations at work. These generational differences lead to a certain point: In order to avoid organizational chaos, it is crucial to manage generational diversities effectively and transform these differences into functional clashes which will benefit the organization and its stakeholders as well.

\footnotetext{
"..according to the generation theory people are changed by, but also change the world around them. Each new generation is socialized by elders into the existing culture, but also simultaneously adds new characteristics resulting from its unique reactions to historical events of the time."
}

(Rasch and Kowske, 2012:2).

Thus, the possible differences in business ethics perceptions among generations may have important effects in the creation of ethical climate. Given this in hand, the aim of this research is to identify the perception of business ethics of these three generations at workplace and to propose possible implications for human resources professionals.

\subsection{Clash of Generations in Turkey}

"When the cold war ended, we thought we were going to have a clash of civilizations. It turns out we're having a clash of generations." (Carnegie Endowment scholar David Rothkopf) 
Since Turkey is a developing country, before 1980s people were not able to follow up the major global developments such as technological innovations. Thus, while Baby Boomers of Turkey were experiencing the hard times of Turkish revolution and transition to multi-party democracy; the world was living the golden age of radio and human rights (Topçuoğlu, 2007). The Baby Boomers who are also called the "sandwich generation" (a generation caught between two generations) have raised their children and looked after their aging parents in the same house. Like their parents, they had great respect towards authority; they were loyal and abstemious and devoted to their companies. This young generation of 1968s was also affected by the global socialist movement and a group of idealists have upraised against the injustice in Turkey.

The following generation, "Generation X" that has entered the workforce during the second half of 1980s was affected from the difficulties of transition to liberal economy, economic crisis and ethnic terrorism in Turkey. On the contrary, their peers in Western societies were experiencing the advantages of flexible working hours and technological advances such as the internet. Generation X, usually adopt their feelings to the situations, thus their commitment and loyalty are flexible; they use technology because they have to, they always seek for better career opportunities, they can easily be motivated and abstemious, they are less sensitive to the social and political issues of their time however they still have a great respect to the authority. Finally, Generation $Y$ in Turkey resembles their peers in the Western countries, as both were born to the age of technology. The gap between generations in Turkey and Western countries diminishes for Generation $Y$ with the progress of transportation and information flow between nations due to technological advancements. Generation Y are individualistic and entrepreneurial; they cannot live without technology and they hate hard work but love success and entertainment. They are against the authority; they want more but they are not ready to pay for this² (Topçuoğlu, 2007).

Today, the Turkish workforce is composed of three different generations (Baby Boomers, Generation X, Generation $Y$ ) that make the managerial practices harder. While one group of employees aims to rise to the peak, some work for status and position and others are motivated by money ${ }^{3}$. This diversification got more complicated for managers with the entrance of Generation Y. Since all these generations have different expectations about recruitment, promotion, wage and way of completing tasks, the organizations are forced to consider these diversifications while establishing their organizational policies (Marston, 2007).

The three generations in Turkey have a lot in common with their peers in USA or other European countries. However, being born in the same time frame does not prove that they are identical. Besides the similarities, there also might be differences about the perception of work related issues because of the "country" specific social, political and economical events experienced during life time.

The literature involves a number of studies on generational cohorts and perception of business ethics most of which is held in Western Cultures (Meriac et al.2010; Twenge, 2010; Marstan, 2007). Due to the impact of cultural differences on workplace issues, it is not proper to use only Western based studies in Turkey. Thus, while the study aims to identify the differences between generations in terms of business ethics, it also contributes to the literature by providing an understanding on generations and their perceptions on business ethics in Turkey, which would be more relevant for Turkish managers to utilize.

\section{Method}

In order to achieve a detailed understanding of the subject, qualitative research methods are adopted for this study (Mariampolski, 2001). By using qualitative methods, a researcher enables respondents to express their thoughts and feelings without any restriction (Levy 1982; Mariampolski, 2001). It also helps to explain the complex processes of creating meaning, deeper feelings and contradictions of mind (Levy, 2005).

\subsection{Sample and Data Collection}

The sample is composed of employees from different age groups working in Izmir ${ }^{4}$, which is the third biggest city in

\footnotetext{
2 http://www.hurriyet.com.tr/gundem/20014287.asp:28.02.2012; http://basin.arsiv.metu.edu.tr/index.php?date=20120106\#section_20903 :06.01.2012

${ }^{3}$ Adopted from http://www.ikportal.com/doc/YeniNesil2008_Rapor.pdf and http://www.kobifinans.com.tr/tr/bilgi_merkezi/020603/19653 : 29.09.2011

${ }^{4}$ www.izmir.bel.tr
} 
Turkey. The employees were randomly selected from various organizations. However, there is no doubt that apart from the generational differences there may be other factors that may influence the answers of the respondents such as age, position and tenure (Sirias, Karp \& Brotherton,2007; Twenge,2010; Hansen \& Leuty,2012). To prevent possible bias, the respondents of each generation are selected from the similar ages and comparable occupational backgrounds with parallel tenures. 18 semi structured interviews ( 6 interviews for each generational cohort as Baby Boomers, Generation $X$ and Generation $Y$ ) were made. The interviews were characterized by a conversational format in which the interview dialogue was set largely by the respondents. Minimum four open-ended questions were asked to all respondents following the same cycle and additional questions were formulated according to respondents' reflections in order to get all the details of their specific experiences. The interviews approximately took an hour and were recorded with the permission of the respondents. Researcher ensured respondents that no personal information would be declared. All of the interviews were conducted in respondents' offices in order to guarantee that they feel comfortable and relaxed.

The interviews began by attaining general background information (age, working experiences, their current organizations and positions) which was summarized in Table-1. In order to ensure that the respondent feels free of talking about the subject, questions were formed in an open-ended way which deepens the conversation. The researcher used probes to let the respondent keep talking and sharing ideas and experiences about the questions. In an independently flowing dialogue format, all the pre-formed questions were asked. The researcher ended interviews by presenting gratitude of the research team and promising to share the final study with the respondents.

Table 1. Generational and Occupational Distribution of the Sample

\begin{tabular}{|c|c|c|}
\hline Generational Cohort & Age & Occupation \\
\hline \multirow{6}{*}{$\begin{array}{l}\text { Baby Boomers } \\
(1946-1964)\end{array}$} & 52 & Head of Board of Directors in Their Own Family Business \\
\hline & 65 & Engineer, Founder and Manager of his own Company \\
\hline & 57 & General Manager / Automobile Parts Producing Company \\
\hline & 58 & Doctor \\
\hline & 61 & Engineer, Founder and Manager of his own Company \\
\hline & 62 & Retired \\
\hline \multirow{6}{*}{$\begin{array}{l}\text { Generation X } \\
\text { (1965-1979) }\end{array}$} & 41 & Product Manager in a private food company \\
\hline & 41 & Responsible from the "production process" in a private food company \\
\hline & 36 & Finance Manager in family firm \\
\hline & 36 & Auditing Director/ Auditing and Consultancy Company \\
\hline & 33 & Head Hunter / Human Resources and Consultancy Company \\
\hline & 35 & Sales Manager / Communications Company \\
\hline \multirow{6}{*}{$\begin{array}{l}\text { Generation Y } \\
(1980-1995)\end{array}$} & 30 & E- Marketing Manager of a Retail Chain \\
\hline & 25 & Manager of Seasonal Sales Shops in a Retail Chain \\
\hline & 30 & Private Accountant \\
\hline & 31 & Engineer- Manager in their own family business \\
\hline & 28 & Architect / Project Team Member in an Architecture Company \\
\hline & 29 & Lawyer / Managing Partner in a Law Firm \\
\hline
\end{tabular}

Each interview was audio taped and transcribed verbatim. Interview records were then transcribed for analysis and analyzed by the researchers; the findings were double checked, categorized and presented as given below.

\subsection{Findings}

Although it is stated in the literature that high potential generational differences with respect to business ethics are expected, there are only a few empirical studies examining these potential differences. Meriac, Woehr and Banister (2010) measured business ethics among generational cohorts and they found out that across the three cohorts; Generation X showed the lowest level in perception of business ethics whereas Baby Boomers have the highest levels. The analysis of the transcripts of this current study presented somewhat diverse findings. Unlike the literature, Baby Boomers and Generation X of our sample gave similar definitions for business ethics. They both defined the term as the right way of doing things by considering consciousness and transparency:

"..For me, business ethics is feeling responsible for all parties, it is trying to do the right thing at all times!...I guess people act more ethical as they mature... I observe it so!" Baby Boomer, 6 
"...with education and training, people became more ethically conscious I think! .... always do the best for my company, my boss and my client...I don't hide any information and this is business ethics!" Generation X, 3

"Business ethics... I think we live in a time...today it is all free to get what you want." Generation Y, 2

Although, the studies about Generation $Y$ present that they have respect for authority, they accept hierarchy and reflect modesty developing from a grounded moral code of conduct and they are able to organize their own business ethics (Duchscher, Cowin; 2004), the results of our study showed contradicting findings. The respondents of Generation $\mathrm{Y}$ in our sample reported their older managers having very strict ethical principles. Also, they stated that some of the ethical rules can be ignored in order to achieve personal success in today's competitive business world. The other two generations also perceive Generation $Y$ to have loose ethical understandings:

"...I think business ethics is a subjective concept....people do anything for their best, I also do it...for my career I can do anything. For example my current boss, gives too much attention to ethical principles which sometimes results with financial loses" Generation Y, 6

"...my colleagues especially the younger ones, I guess they don't have ethical orientation as we do..." Baby Boomer, 2

“...my boss and people who were born before 1975s, they are ethical... Generation Y, 1

Throughout the literature; it is seen that most of the studies express a decline in the perception of business ethics. New generations are less fond of working overtime and they do not feel proud of their occupations. Older generations mostly have complaints about business ethics perceptions of younger generations (Smola \& Sutton; 2002, Twenge; 2010). The same thing applies for our sample, as seen in the quotations above, Baby Boomers believe that the new generation especially the ones which are defined as Generation $Y$, do not obey ethical rules. Also, Generation $Y$ perceives Baby Boomers and Generation $X$ as more ethically oriented than they are. For example, Generation $Y$ employees do have ethical orientation, they take the responsibility of working for long hours in the workplace, but this is not a reflection of a strong ethical perception, it is merely due to the coercion of employers (Twenge, 2010). In fact, these results are not surprising since Generation $Y$ believes that career and education are more important than work related norms and values such as loyalty, commitment and ethical orientation (Topçuoğlu, 2007, Twenge, 2010).

\section{Discussion}

The modern workplace is characterized as a place where people from different ages, genders, religions and races come together. This diversified composition of individuals mostly emerges as a source of problem and unrest. Thus, organizations and managers try harder to grant harmony in the work place. As young people enter the workforce, the diversity of generations enriches. Along with this progress, different generational cohorts have to work together. Even though having a variety of generational cohorts provides opportunities and advantages for the organizations, the differences in their perceptions and characteristics may cause disadvantages at the same time. Especially, this situation puts responsibility on the shoulders of managers in terms of managing different age groups in order them to be in accordance and creating the right composition of work force.

There have been a number of studies that focused on the workplace attitudes and generations. (Deal, 2007; Elmore, 2010; Gesell, 2010; Joshi et al, 2010; Lancaster \& Stillman, 2004; Li \& Nimon,2008; Marston, 2007; Nancy, 2009; Reisenwitz \& lyer 2009; Salahuddin, 2010; Simons,2010). The related literature presents these studies but since most of these studies are Western based, the results can be relevant solely for Western Cultures. This study was initiated with the motive to provide information and insight about generational differences on business ethics in Turkey. The results suggest that, there are some differences and similarities about the perceptions of business ethics among three different generational cohorts. Whereas Baby Boomers and Generation X define business ethics by relating the concept to transparency, a feeling of responsibility and care for others; Generation $Y$ does not sound even willing to define what it is. Thus, one of the most noticeable findings was about the decline of ethical orientation among young generations. Although they are called as the most "high maintenance and productive" (Tulgan, 2009) work force, Generation $\mathrm{Y}$ is found to be the least ethically oriented employees of today.

Given these findings, managers should design programs to enhance their ethical orientation by conducting ethical training programs, strictly implementing ethical codes and supporting ethical behavior. In order to grant a peaceful climate in the work place, special programmes which would create the opportunity for different generations to come together and 
share ideas, experiences and beliefs would be useful as the lack of communication and mutual understanding among generations is the source of gap between them (Lancaster \& Stillman; 2002).

Managers should also focus on designing human resources (HR) policies by taking into consideration the differences and similarities. In order to empower employees and increase organizational commitment, different HR programmes should be developed in order to meet different needs of generations.

New times create new points of view and new people. Managing diversity and succeeding in making the best out of such a work force is challenging. Motivating organizational members in a world of lesser boundaries and more virtual possibilities requires managers to learn more, try harder and try continuously. This study provides some of the necessary insight for managers especially the human resources managers to deal with organizational members and their organizational duties, career issues and workplace problems. By utilizing the current findings, managers can both attract new successors from Generation $X$ and Generation $Y$ and at the same time continue benefiting from competence of Baby Boomers.

To note the limitations of the study; research has taken place in only a certain part (Aeagean Region) of Turkey with a restricted number of respondents. In the future, the study can be extended to other regions of the country with larger samples and by adding new variables that are important for managerial issues, as there are variations among regions which may present differences in generational diversifications.

\section{References}

Anand, V., Ashforth, B.E. ve Joshi, M. (2005) "Business as Usual: The acceptance ve perpetuation of corruption in organizations", Academy of Management Executive, (4), 9-23

Adams, S. J. (2000). Generation X: how understanding this population leads to better safety programs. Professional Safety 45: 26-29.

Bachman, J. G., Smith, C. B., \& Slesinger, J. A. (1966). Control, performance and satisfaction: An analysis of structural and individual effects. Journal of Personality and Social Psychology, 4, 127-136.

Bass, B.M. (1990). Bass and Stodgill's Handbook of Leadership. New York: The Free Pres

Beutell, N. J., \& Wittig-Berman, U. (2008). Work-family conflict and work-family synergy for generation X, Baby Boomers, and matures: Generational differences, predictors, and satisfaction outcomes. Journal of Managerial Psychology, 23(5), 507-523.

Chowdhury, T.G., \& Coulter, R.A. (2006). Getting a 'Sense' of Financial Security for Generation Y. American Marketing Association Conference Proceedings Chicago, Vol. 17, 191.

Deal, J. J., (2007). Retiring the Generation Gap: How Employees Young and Old Can Find Common Ground, San Fransisco: JosseyBass.

Durkin, D. (2008). Youth Movement. Communication World, Vol. 25, pp. 23-26.

Dziuban, C.D., Moskal, P.D., Hartman, J. (2005). Higher education, blended learning, and the generations: Knowledge is power: No more. In J. Bourne \& J.C. Moore (Eds.), Elements of Quality Online Education: Engaging Communities. Needham: MA: Sloan Center for Online Education.

Ebrahim, A., (2003). Accountability In Practice: Mechanisms for NGOs. World Development, Vol.31, No.5, pp.813-829.

Edwards, M. \& Hulme, D. (1996). Beyond the Magic Bullet: NGO Performance and Accountability in Post-Cold War World. USA Kumarian Press.

Elmore, L. (2010). The Workplace Generation Gaps, Women in Business, .8-11.

Ferrell, O.C., Fraedrich, J. ve Ferrell L., 2011, Business Ethics: Ethical Decision Making and Cases, $8^{\text {th }}$ Edition, South Western Cengage Learning: USA

Freestone,G. \& Mitchell, V.W. (2010). Generation Y Attitudes Towards E-ethics and Internet-related Misbehaviours. Journal of Business Ethics, 54, 121-128.

French, J.R.P. \& Raven, B. (1959). The Bases of Social Power. Studies in Social Power. p:150-167.

Fry, R. E. (1995). Accountability in organizational life: Problem or opportunity for nonprofits? Nonprofit Management and Leadership, 6(2). 181-195.

Gardiner, S.M. (2004). Ethics and Global Climate Change. Ethics, 114. 3; 555-600.

Gesell, I.(2010). How to Lead When the Generation Gap Becomes Your Everyday Reality.The Journal of Quality and Production.available online at: www . asq. org/pub/jqp :29.09.2011.

Gravett, L. \& Throckmorton, R. (2007).Bridging the Generation Gap: How to Get Radio Babies, Boomers, Gen Xers, and Gen Yers to Work Together and Achieve More, New Jersey: Career Pres.

Hartman, L.P. \& Desjardins, J. (2008). Business Ethics: Decision Making, Personal Integrity and Social Responsibility, $8^{\text {th }}$ Edition. Mc Graw Hill: New York.

Joshi, A., Dencker, J.C., Franz, G. \& Martocchio, J.J.(2010). Unpacking Generational Identities in Organizations, Academy of Management Review, 35:3. 392-414.

Kupperschmidt, B.R. (2000). Multigeneration employees: strategies for effective management. The Health Care Manager 19. 65-76.

Kanter, R.M. (1979). Power Failure in Management Circuits. Harvard Business Review. p69. 
Lancaster, L.C. \& Stillman, D. (2004). When Generations Collide: How to Solve the Generational Puzzle at Work, HarperCollins ebooks.

Lescohier, J. (2006). Generation Y. . . Why Not? Rental Product News, Vol. 28. 40-44.

Levy, S.J. (2005). The evolution of qualitative research in consumer behavior. Journal of Business Research. 58(3) , 341- 47.

Li, J. \& Nimon, K. (2008). The importance of recognizing generational differences in HR policy and practices: a study of workers in Qinhuangdao, China. Human Resource Development International, 11:2. 167-182.

Mariampolski, H. (2001). Varieties of Qualitative Research. Qualitative Market Research : A Comprehensive Guide. 46-54.

Marston, C. (2007). Motivating the "What's in it for me?" Workforce: Manage Across the Generational Divide and Increase Profits, New Jersey: John Wiley and Sons, Inc.

Meriac, J ., Woehr, D.J. \& Banister, C. (2010). Generational Differences in Work Ethic: An Examination of Measurement Equivalence Across Three Cohorts, Journal of Business Psychology, 25.315-324.

Mitchell, M.A., McLean, P. \& Turner, G.B., 2005. Understanding Generation X: Boom or bust Introduction, Business Forum, 27:1. 2630.

Nancy R., Lockwood, N.R. (2009). The Multigenerational Workforce: Opportunity for Competitive Success. Society for Human Resource Management, First Quarter Project.

Orrell, L. (2009). In Economic Crisis, Think of the Next Generation, Strategic Communication Management, Vol. 13. February/March, p. 7.

Passyn, K. \& Juan, M. (2006). Self-Accountability Emotions and Fear Appeals: Motivating Behavior. Journal of Consumer Research, 32. 583-589.

Podsakoff, P.M. \& Schriesheim, C.A., (1985). Field Studies of French and Raven's Bases of Power: Critique, Reanalysis, and Suggestions for Future Research. Psychological Bulletin, 97. 3.387-411.

Raven, B.H. \& French,J. (1958). Legitimate Power, Coercive Power, and Observability in Social Influence. Sociemetry, 21(2)

Read, E. (2007). People Management: Myth-Busting Generation Y - Generational Differences at Work; Don't Understand Your Younger Colleagues? Think They Have Different Work Attitudes to You? Always Blamed it on the Generation Y Factor? Well Those Days May be Over as a Major Study on Workplace Attitudes in New Zealand Dispels the Hype About the Differences Between Generations X, Y and Baby Boomers, New Zealand Management. November, p. 63.

Reed, C. (2007). Generation Y Research: What Makes Y Tick", Brand Strategy, February 5.p. 38.

Robbins, P.S. \& Judge, T.A. (2009). Organizational Behavior, New Jersey: Pearson Education.

Reisenwitz, T. \& Iyer, R. (2009). Differences in Generation X and Generation Y: Implications for the organization and marketers, The Marketing Management Journal, 19:2. 91-103.

Salahuddin, M.(2010). Generational Differences Impact On Leadership Style and Organizational Sucess. Journal of Diversity Management, 5:2.1-6.

Simons, N.(2010). Leveraging Generational Work Styles, to Meet Business Objectives, Innovation Management.

Sirias, D., Karp, H.B.,\& Brotherton, T. (2007). Generational Differences in Work Values: Leisure and Extrinsic Values Increasing, Social and Intrinsic Values Decreasing. Journal of Management, 36:5. 117-1142.

Smola, K.W. \& Sutton, C. (2002). Generational differences: Revisiting generational work values for the new millennium. Journal of Organizational Behavior, 23. 363-382.

Topçuoğlu, M.C.(2007). İyi de kim bu Y'ler. Reklamcılar Derneği. available online at: http://www.rd.org.tr/ayinsozu/AyinSozuAgustos.pdf : 29.09.2011

Trevino, L.K., Weaver, G. R., ve Reynolds, S., (2006), Behavioral ethics in organizations, A review. Journal of Management, 32(6), 951990

Twenge,J.M.(2010) A Review of the Empirical Evidence on Generational Differences in Work Attitudes. Journal of Business Psychology, 25:201-210

Thamhain, H. J., \& Gemmill, G. R. (1974). Influence styles of project managers: Some project performance correlates. Academy of Management Journal, 17. 216-224.

U., Pareek. (2006). Organisational Leadership and Power, ICFAI University Press: India http://www.rd.org.tr/ayinsozu/ AyinSozuAgustos.pdf :29.09.2011.

Velasquez, M.G., 2012, Business Ethics: Concepts and Cases, $7^{\text {th }}$ Edition Pearson: New Jersey 